\title{
A PRELIMINARY STUDY ON THE POLYMORPHISM OF HYPERVARIABLE D17S5 LOCUS IN UNIMAS CHINESE POPULATION
}

\author{
HAIRUL AZMAN ROSLAN*, JESSIE ANN SIM CHIEW LING \& ROSMAWATI SAAT \\ Department of Molecular Biology, Faculty of Resource Science and Technology, \\ Universiti Malaysia Sarawak, 94300 Kota Samarahan, Sarawak
}

\begin{abstract}
Variable number of tandem repeats (VNTRs) is one of the most useful tools in the study of polymorphism and have spurred studies in many populations throughout the world. Here we report a preliminary VNTR study of the polymorphism of the hypervariable locus D17S5, in the Chinese community in UNIMAS. Samples were obtained from seventy-five unrelated Chinese individuals. The study showed the presence of six alleles ranging from $170 \mathrm{bp}$ to $520 \mathrm{bp}$ in sizes. The allele frequencies ranged from 0.02 to 0.44 with heterozygosity value of 0.32 . The distributions of the D17S5 alleles in the UNIMAS Chinese population were also determined with allele 2 having the highest frequency and alleles 5 and 6 being the lowest frequencies, respectively.
\end{abstract}

Keywords: VNTR, D17S5, polymerase chain reaction, forensic identification, allele distribution

\section{INTRODUCTION}

Approximately $30 \%$ of the human genome is made up of human tandem repeats. Human minisatellites or variable number tandem repeat (VNTR) loci have repeat units of between 6 to more than 100 base pairs long, depending on the locus, and are codominance (Tamaki \& Jeffreys 2005). The high polymorphism characteristic of VNTRs makes them suitable markers for use in genetic identification, forensic medicine, paternity testing and population genetics (Gasparini et al. 1991; Hartl \& Clark 1997). The VNTR D17S5 locus is located on chromosome number 17 and comprise of 19 repeat units (Horn et al. 1989; Kijas et al. 1994; Pinheiro et al. 1996). The repeat unit has tandem repeats of 70 base pairs and alleles range from $170 \mathrm{bp}$ to $1430 \mathrm{bp}$ in length.

Database for hypervariable locus, especially D17S5, in the Malaysia population has not been well established for many of the races especially in Sarawak. Previous similar studies were conducted in Peninsular Malaysia looked at the polymorphism in several markers such as the mitochondrial DNA, CYP2C9 enzyme and the use of cytochrome P450 (Yang et al. 2004; Hoong \& Lek 2005; Zainuddin et al. 2006). The Chinese community in UNIMAS came from all over Malaysia including Sabah and Sarawak. Therefore

*Corresponding author: rhairul@frst.unimas.my this study would eventually enable further population studies such as in the origin; ancient migration and movement of the Chinese community can be studied. Here we report a preliminary analysis of the D17S5 locus from the Chinese population in UNIMAS.

\section{MATERIALS \& METHODS}

\section{Sample Collection and DNA extraction}

A non-invasive method of DNA sample collection was conducted by buccal swab technique and DNA isolation was conducted (Richards et al. 1993). Samples were collected from 75 unrelated individuals. Informed consent was obtained from all donors before the DNA samples were collected.

Polymerase Chain Reaction (PCR) and Gel analysis

PCR of hypervariable locus was conducted in $25 \mu 1$ total PCR volume consisted of $7.5 \mu$ l sterile water, $2.5 \mu \mathrm{l} 10 \mathrm{X}$ buffer with (NH4) $\mathrm{SO}_{4}$ (Vivantis), $1 \mu \mathrm{l}$ $10 \mathrm{mM}$ dNTP mix (Fermentas), $1 \mu \mathrm{L}$ D17S5 Forward primer (5'-CACAGTCTTTATTCTTCAGCG-3'), $1 \mu 1 \quad$ D17S5 Reverse primer (5'CGAAGAGTGAAGTGCACAGG-3'), $0.5 \mu \mathrm{l}$ of 


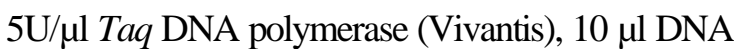
and $20 \mu \mathrm{l}$ mineral oil. The PCR condition was as follows; denaturation at $94^{\circ} \mathrm{C}$ for 30 seconds,annealing at $65^{\circ} \mathrm{C}$ for 1 minute, amplification at $72^{\circ} \mathrm{C}$ for 1 minute, final extension at $72^{\circ} \mathrm{C}$ for 10 minutes and the PCR was repeated 30 cycles. PCR products were analysed in $1.2 \%$ agarose gel in 1X TAE (Tris base, glacial acetic acid, $0.5 \mathrm{M}$ EDTA) and documented using Kodak Gel Documentation System.

\section{Statistical Analysis}

Statistical analysis of data were calculated using equation by Carr (2004).

$\mathrm{f}(\mathrm{A})=(2 \mathrm{x}+\mathrm{y}) / 2 \mathrm{~N}$,

*where $f$ represents the allele frequency, $x$ represents homozygote individuals, y represents heterozygote individuals and $\mathrm{N}$ represents the sample size.

\section{RESULTS AND DISCUSSION}

A total of six different sizes were generated from the PCR representing the alleles in D17S5 locus ranging from 170bp to 520bo (Figure 1). Table 1 shows the number of homozygotes and heterozygotes and the allelic frequencies for the D17S5 locus calculated using the equation by Carr (2004). Allele 2 was found to be the most frequent allele (0.44) while alleles 5 and 6 exhibited the lowest frequency ( 0.02 each).

Similar studies on the allele frequency distribution of the D17S5 locus showed that 12 alleles were observed in the North Vietnamese population, 10 alleles were found in the Japanese population, and 10 alleles were found in both the Northern Han and the Hui populations (Katsuyama et al., 1998). In the Vietnamese population, allele B8 was the most common allele (14.7\%) with a heterozygosity value of $83.76 \%$. The most frequent alleles found in the Japanese population was allele number 4 while allele number 1 was the most frequent in both the Northern Han and the Hui populations. The observed heterozygosity values in the Japanese, Northern Han and Hui populations were $0.774,0.0341$ and 0.909 respectively. The Chinese community in this study showed a heterozygosity value of 0.32 which was higher than the value of the Northern Han population living in Xining, China but lower than those found in the Japanese and the Hui populations.

On the other hand, additional comparison of the D17S5 allelic frequency in the Chinese community samples with the Melanau population of Sarawak (Sulaiman, 2006, unpublished data) indicated that the Melanau population has 3 additional alleles compared to the Chinese samples, with the highest frequency found was allele number 1 while the lowest frequency were alleles number 7 and 9 , but with lower observed heterozygosity value (0.1935).

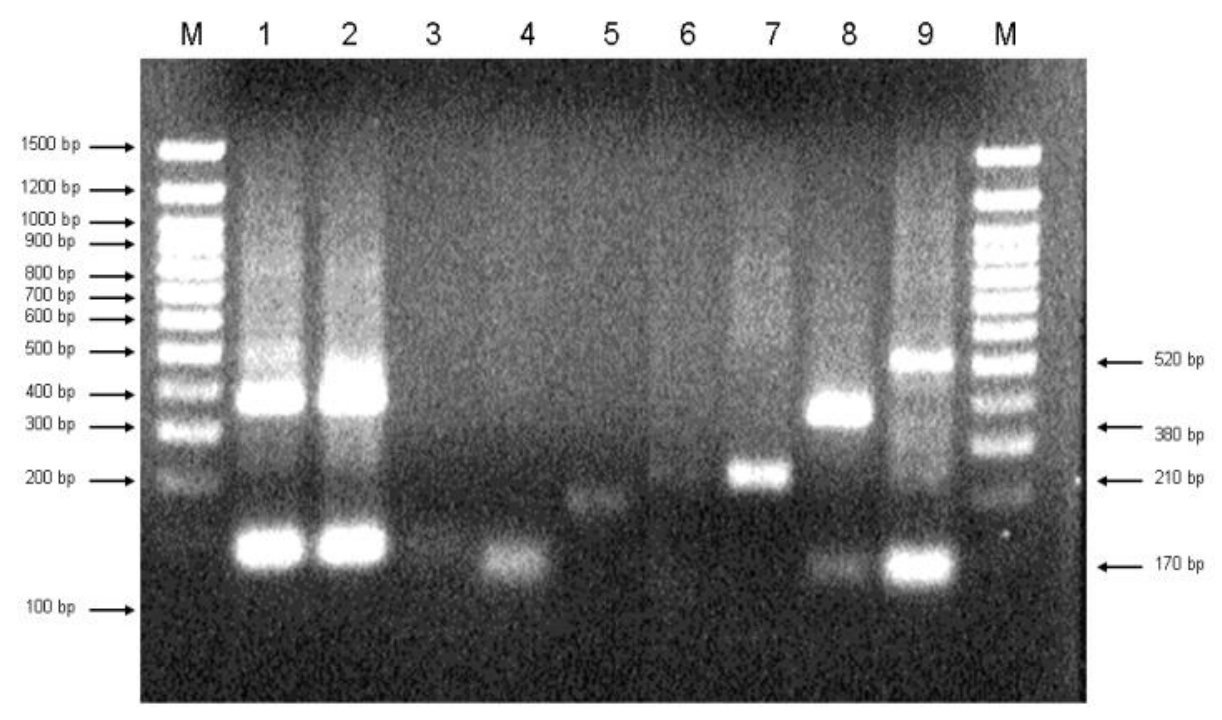

Figure 1. Agarose gel electrophoresis of D17S5 PCR products. Lanes 1-9 are the PCR products representing the 4 alleles present in the population. Lanes $\mathrm{M}$ are the Forever 100 base pairs ladders (Seegene). 
Table 1. Allele frequencies calculated according to the equation reported by Carr (2004) for the different alleles.

\begin{tabular}{ccccc}
\hline Allele & Size & $\begin{array}{c}\text { Number of } \\
\text { homozygotes }\end{array}$ & $\begin{array}{c}\text { Number of } \\
\text { heterozygotes }\end{array}$ & Allele frequency \\
\hline 1 & 170 & 8 & 15 & 0.31 \\
2 & 240 & 18 & 8 & 0.44 \\
3 & 310 & 4 & - & 0.08 \\
4 & 380 & 4 & 6 & 0.14 \\
5 & 450 & 1 & - & 0.02 \\
6 & 520 & - & 2 & 0.02 \\
\hline
\end{tabular}

\section{CONCLUSION}

This study has successfully amplified and resolved the D17S5 alleles. The various sizes of the alleles were determined and 6 different alleles were found in the Chinese population of UNIMAS that ranged from 170 base pairs to 520 base pairs. The statistical analyses carried out also showed that the highest frequency was allele number 2 while the lowest allelic frequencies were allele number 5 and 6 . The distributions of alleles of the Chinese population in UNIMAS were also found not to be evenly spread.

\section{ACKNOWLEDGEMENTS}

The authors wish to thank the Faculty of Resource Science and Technology for the facilities to conduct the work.

\section{CONSENT STATEMENT}

Prior to the start of the project, this project have been reviewed by UNIMAS Ethical Committee for Research and have been given consent to be performed. The procedures of the protocols are within the guidelines of the 1964 Declaration of Helsinki. The donors for DNA samples have been informed prior to donation of the purpose of the project and that the DNA will be kept confidential. Upon agreeing to the conditions, the donors DNA was then labeled anonymously and only used for the said project. Subsequent DNA samples that are not used are disposed of via autoclave.

\section{REFERENCES}

Carr, S. M. (2004). Principles of human population genetics. Memorial University of Newfoundland Website: http://www.mun.ca/biology/scarr/6390_ Population_Genetics.html
Gasparini, P., Mandich, P., Novelli, G., Bellone, E., Sangiuolo, F., De Stefano, F., Potenza, L., Trabetti, E., Marigo, M., Pignatti, P. F., Dallapiccola, B. \& Ajmar F. (1991). Forensic applications of molecular genetic analysis: An Italian collaborative study on paternity testing by the determination of variable number of tandem repeat DNA polymorphisms. Human Heredity, 41:174-181.

Hartl, D. L. \& Clark, A. G. (1997). Principles of Population Genetics ( $3^{\text {rd }}$ Ed.). Sinauer.

Hoong, L. L. \& Lek, K. C. 2005. Genetic polymorphisms in mitochondrial DNA hypervariable regions I, II and III of the Malaysian population. Asia Pacific Journal of Molecular Biology and Biotechnology 13:2 79-85.

Horn, G. T., Richards, B. \& Klinger, K. W. (1989). Amplification of a highly polymorphic VNTR segment by the polymerase chain reaction. Nucleic Acids Research 17(5): 2140.

Katsuyama, Y., Inoko, H., Imanishi, T., Mizuki, N., Gojobori, T. \& Ota, M. (1998). Genetic relationships among Japanese, Northern Han, Hui, Uygur, Kazakh, Greek, Saudi Arabian, and Italian populations based on allelic frequencies at four VNTR (D1S80, D4S43, COL2A1, D17S5) and one STR (ACTBP2) loci. Human Heredity, 48: 126-137.

Kijas, J. M. H., Fowler, J. C. S. \& Van Daal, A. (1994). PCR amplification of alleles at locus D17S5: Detection of new and rare long-length alleles by oligoprobing in a survey of Australian populations. Website $h t \mathrm{tp} / / / \mathrm{www}$. findarticles.com/p/articles/mi_qa3659 /is_199404/ai_n8729501. 
Pinheiro, M. F., Pontes, M. L., Huguet, E., Gene, M., Pinto da Costa, J. \& Moreno, P. (1996). Study of three AMPFLPs (D1S80, 3'ApoB and YNZ22) in the population of the North of Portugal. Forensic Science International, 79: 23-29.

Richards, B., Skoletsky, J., Shuber, P. A., Balfour, R., Stern, R. C., Dorkin, H. L., Parad, R. B., Witt, D. \& Klinger, K. W. (1993). Multiplex PCR amplification from the CRFT gene using DNA prepared from buccal brushes/swabs. Human Molecular Genetics, 2: 159-163.

Sulaiman, N. S. (2006). Allele frequencies distribution of hypervariable loci in Melanau population sample of UNIMAS. Final Year Project, Universiti Malaysia Sarawak, Kota Samarahan. Unpublished.
Tamaki, K. \& Jeffreys, A. J. (2005). Human tandem repeat sequences in forensic DNA typing. Journal of Legal Medicine, 7(4): 244-250.

Yang, Y. S., Wong, L. P., Lee, T. C., Mustafa, A. M., Mohamed, Z. \& Lang C. (2004). Genetic polymorphism of cytochrome P450 2C19 in healthy Malaysian subjects. British Journal of Clinical Pharmacology 58:3 332-335.

Zainuddin, Z., Teh, L. K., Suhaimi, A. W. M. \& Ismail, R. (2006). Malaysian Indians are genetically similar to Caucasians: CYP2C9 polymorphism. Journal of Clinical Pharmacy and Therapeutics 31:2 187-191. 